\title{
Harnessing the aphid life cycle to reduce insecticide reliance in apple and peach orchards. A review
}

\author{
Aurélie Rousselin $^{1}$ • Daniele Bevacqua ${ }^{1}$ Marie-Hélène Sauge ${ }^{1} \cdot$ Françoise Lescourret $^{1}$ \\ Karsten Mody ${ }^{2} \cdot$ Marie-Odile Jordan $^{1}$
}

Accepted: 21 July 2017 /Published online: 23 August 2017

(C) INRA and Springer-Verlag France SAS 2017

\begin{abstract}
Apple and peach orchards are chemicalintensive systems, and aphids are one of their major pests. Aphids alter fruiting and shoot development, and they can spread viruses. Decades of insecticide use have developed aphid resistance, which calls on research to provide alternatives to chemicals for pest management. Here, we review the literature to identify, for each stage of the aphid life cycle, existing alternatives based on either top-down (i.e. aphid predation or parasitism) or bottom up (i.e. increase of host plant resistance) processes. Firstly, it was found that most studies focus on topdown processes, namely on conservation biological control aiming to preserve existing populations of natural enemies: predators, parasitoids and nematodes. This is achieved by (i) providing shelters (i.e. planting hedges, weed or flower strips) or alternative preys in periods of aphid scarcity or (ii) choosing chemicals with the lowest disruptive effects. Those methods prove more efficient when used early in the season, i.e. before the exponential increase of aphid populations. Fostering the complex of natural enemies is also preferable than just supporting one single enemy. Secondly, other techniques, like (i) releasing biological control agents (entomopathogenic fungi, nematodes) or (ii) using pheromone lures to prevent autumnal sexual reproduction, are currently adapted
\end{abstract}

Marie-Odile Jordan

marie-odile.jordan@inra.fr

1 INRA, UR1115 Plantes et Systèmes de culture Horticoles (PSH), Domaine St Paul, Site Agroparc, 84914 Avignon Cedex 09 Avignon, France

2 Ecological Networks, Biology, Technische Universität Darmstadt, Schnittspahnstr. 3, 64287 Darmstadt, Germany for their use in orchard conditions. Thirdly, bottom-up regulation has to be devised as a long-term strategy, which could start by choosing a cultivar enabling genetic avoidance or developing genetic resistance. Then, aphid development can be reduced by the control of shoot growth or nitrogen accumulation in response to pruning or moderate water and nutrient inputs. At last, autumnal return of aphids could be disrupted by techniques such as kaolin applications that impair aphid host plant location. It is concluded that these alternative methods have to be adapted to local conditions and combined in long-term strategies in order to decrease the infestation risks throughout the orchard lifespan.

Keywords Pest management $\cdot$ Apple tree $\cdot$ Peach tree . Aphids $\cdot$ Alternative methods

\section{Contents}

1 Introduction

2 Aphid species infesting apple and peach orchards

3 Bottom-up and top-down control methods at different aphid life cycle phases

3.1 Egg hatching

3.1.1 Bottom-up: genetic avoidance

3.1.2 Top-down

3.2 Parthenogenetic reproduction

3.2.1 Bottom-up

3.2.2 Top-down

3.3 Autumnal return (dioecious species)

3.3.1 Bottom-up: impairing host plant location and decreasing host plant suitability

3.3.2 Direct action: use of sexual pheromone lures to impair mating partner location and reduction of aphid inoculum 
3.3.3 Top down: web-building spiders

3.4 Overwintering forms

4 Side effects of alternative methods to chemicals for aphid control

4.1 Orchard pest community complexity

4.2 Fruit production and quality

5 Conclusion

Acknowledgments

References

\section{Introduction}

Apple and peach are the major fruit crops worldwide. In 2013, according to the FAO (Food and Agricultural Organization) data on world deciduous fruit tree production, apple ranked 1 st with a yearly production of more than $80.10^{6}$ tons, while peach and nectarine ranked 4th with more than $21.10^{6}$ tons, behind grapes and pear (FAO 2016).

Aphids are considered as major peach and apple pests under temperate and Mediterranean climates. First, they can harm fruit production by their detrimental effects on fruit quality, including reduction of fruit size (Filajdić et al. 1995), deformation of fruit shape (Hullé et al. 2006) or premature fruit fall (Van Emden et al. 1969). Second, they reduce overall tree vigour due to phloem sap intake, organ deformation (leaf rolling, shoot twisting), chlorosis, sooty mould development on honeydew and leaf fall (Dedryver et al. 2010). These effects can result in a decrease in $\mathrm{C}$ reserves and so alter long-term growth (Zvereva et al. 2010). Third, aphids can be vectors of virus transmission, including the plum pox virus, which leads to tree death (Rimbaud et al. 2015). The action threshold levels for insecticide application are low, with 1-2\% of infested shoots for Dysaphis plantaginea (Passerini) and 8-10\% for Aphis pomi (De Geer) (Barbagallo et al. 2007). Sometimes a single leaf deformation is enough to trigger insecticide application, due to fear of virus transmission (Penvern et al. 2010). However, data on yield loss attributable to aphids in fruit trees are scarce relative to data available for annual crops (e.g. wheat, sugar beet, potatoes (Dedryver et al. 2010)). Nevertheless, direct evaluation in an organic apple orchard attributes $21.4 \%$ of unmarketable apple fruits to D. plantaginea damage (Simon et al. 2011a). A modelling approach suggested a strong negative impact (more than $5 \%$ reduction in fruit growth) of $D$. plantaginea on apple fruit growth even at low aphid density (De Berardinis et al. 1994). The small number of dedicated studies may be explained by a seemingly low impact of aphids on current year fruit yield. Indeed, several studies have shown that aphid density has almost no effect on the current year yield (Filajdić et al. 1995; Grechi et al.
2008) but possibly on that of future years due to the reduction of tree vigour. Thus, multi-year experiments are needed to quantify aphid impact on yield, as suggested by a modelling approach in which aphid impact was only detected in a multi-year perspective (Bevacqua et al. 2016).

Nowadays, chemical insecticides are still widely used to control aphid populations in peach and apple orchards (Simon et al. 2011a), but due to high environmental costs and implementation of restrictive guidelines, alternatives to chemicals are needed. Moreover, pest populations resistant to chemicals have developed. A single clone of $D$. plantaginea can accumulate several resistance mechanisms conferring resistance to diverse insecticides (Delorme et al. 1999). Seven different mechanisms of resistance to insecticides have been identified in Myzus persicae (Sulzer), enabling this species to withstand many chemicals (Bass et al. 2014). Moreover, for a single mechanism, such as target site resistance to pyrethroids in $M$. persicae, the resistance can depend on several loci and different alleles which can coexist in a single individual (Panini et al. 2015). Another detriment of pesticide use is the perturbation of natural enemies. Laboratory studies showed for instance that some insecticides are lethal to ladybeetles and lacewings (Garzón et al. 2015) and reduced the predation activity of earwigs having been exposed to pesticides (Malagnoux et al. 2015a). In apple orchards, earwig occurrence decreased with the increase of insecticide treatments (Malagnoux et al. 2015b). The spider community was also negatively affected by the use of insecticides in organic apple orchards (Marliac et al. 2016). The side effects of pesticides could possibly be reduced by changing the mode of application, using for instance, trunk injection (VanWoerkom et al. 2014), or applying less toxic substances such as insecticidal soap (Karagounis et al. 2006). Another solution is to seek alternative methods to chemicals (Fig. 1).

In an ecosystem, herbivorous insect abundance is controlled by both top-down and bottom-up processes (Hunter and Price 1992), i.e. by the abundance and voracity of their natural enemies and by the quality and suitability of their host plant. Both control levels could be exploited for a more sustainable pest management. This review presents the alternative methods to chemicals for aphid management in apple and peach orchards adapted to each stage of the aphid life cycle. We start therefore with a quick overview of the diverse life cycles of aphid species infesting apple and peach trees. Then, the possible alternatives mobilising both bottomup and top-down processes are presented for each aphid life cycle stage. Their side effects on other orchard pests and pathogens, and on fruit yield are finally evaluated. 
Fig. 1 Left photograph, aphid colony on apple tree. Right photograph, ladybeetle larva and pupa on apple tree

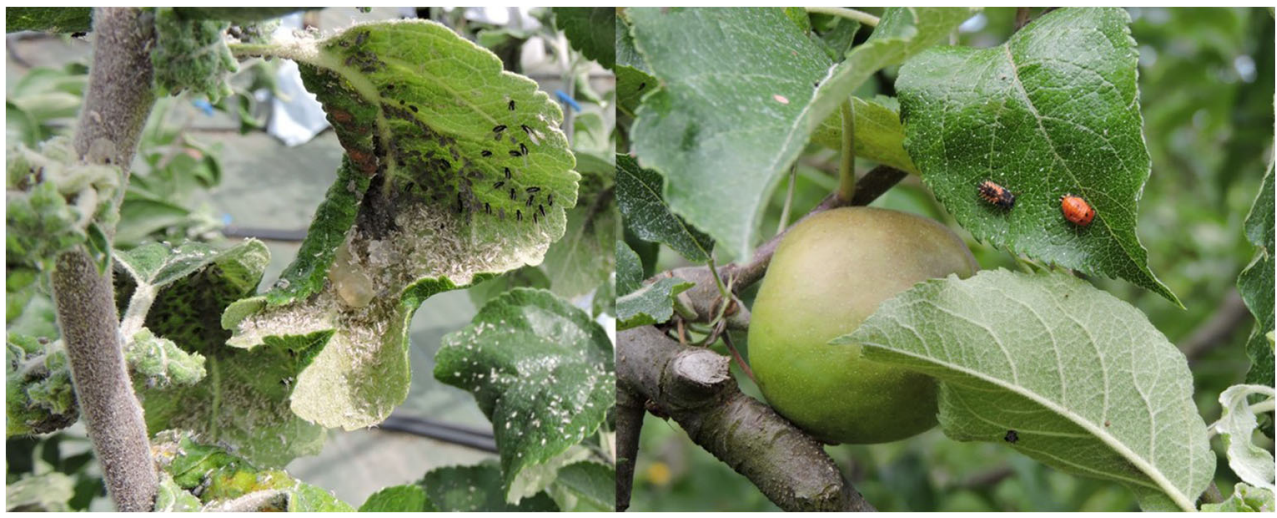

\section{Aphid species infesting apple and peach orchards}

Numerous aphid species - with different life cycles (Fig. 2) are able to colonise and damage peach and apple trees (examples in Table 1). Some species are monoecious (M in Table 1), i.e. they stay on their woody host species all year round, others are dioecious (D in Table 1), i.e. they alternate during the year between a primary host, on which aphids overwinter (the woody host plant), and a secondary host (usually an herbaceous plant), on which aphids spend the summer season. Aphid life cycles are characterized by multiple generations of parthenogenetic reproduction, with females asexually giving birth to female instars. If the parthenogenetic generations are interrupted by one generation of sexual reproduction in autumn, the cycle is called holocyclic (H in Table 1). In that case, sexual females lay cold resistant eggs after mating. In dioecious species, the gynoparae performs the migration between the two host plants and then mate. In monoecious species, the sexual female is called the sexuparae. Then, in spring, eggs hatch, giving birth to the fundatrices (wingless stem mothers). If the parthenogenesis is continuous, the cycle is qualified as anholocyclic (A in Table 1). To face adverse conditions, such as crowding or poor host quality, as well as to enable migration between host plants for dioecious species, aphids can produce winged morphs (Moran 1992; Hardy et al. 2015).

\section{Bottom-up and top-down control methods at different aphid life cycle phases}

Modification of host plant suitability through genetic resistance or modification of the abiotic environment, which exert bottom-up regulation on aphid populations (Fig. 3), embraces several aspects: (i) nutritional quality of phloem sap, which is mainly defined by the amino acid profile (Ryan et al. 2015) and the absence of defensive compounds (Czerniewicz et al. 2011)), (ii) phloem sap accessibility, which is related to physical properties like viscosity or turgor pressure (Smith and
Chuang 2014), (iii) settlement site availability, which corresponds for most orchard aphid species to the number of growing apices, (iv) plant architecture, branching complexity and connectivity of the plant entities (Costes et al. 2012) and (v) canopy microenvironment (Pangga et al. 2012).

In addition to bottom-up regulation, diverse organisms can exert a top-down regulation of aphid populations through predation or parasitism (Fig. 3) and can so be considered as biocontrol agents: natural enemies, i.e. predators and parasitoids, entomopathogenic fungi and nematodes. Generally, three main approaches of biological control are distinguished: (i) conservation biological control, which is based on enhancement of biocontrol agents naturally occurring in the field, (ii) biological control by augmentation, which consists in the release of biocontrol agents and (iii) introduction biological control (not treated in this review), which aims at managing exotic pests through the introduction of their natural enemies (Hopper 2003).

\subsection{Egg hatching}

\subsubsection{Bottom-up: genetic avoidance}

The synchronisation of host plant phenology and aphid life cycle is of prime importance for the success of fruit tree infestation by aphids in spring. Cultivar choice, or more specifically, the precocity of the chosen cultivar, can impair spring aphid settlement through phenological avoidance. Indeed, fundatrices are not well-armed to face unfavourable conditions (Moran 1992). So, if aphid eggs hatch while bud burst of the host plant has not yet started, the fundatrices will not be able to find new leaves to feed upon and so their survival might be strongly compromised (Dapena and Miñarro 2001). As a possible consequence of asynchrony between aphid hatching and bud burst, late bud bursting apple cultivars are less infested and damaged by $D$. plantaginea than early bud bursting cultivars (Miñarro and Dapena 2007). Indeed, developmental processes of both aphids (Pruess 1983; Satar et al. 2008; Nematollahi et al. 2016) and host plants (Kervella 


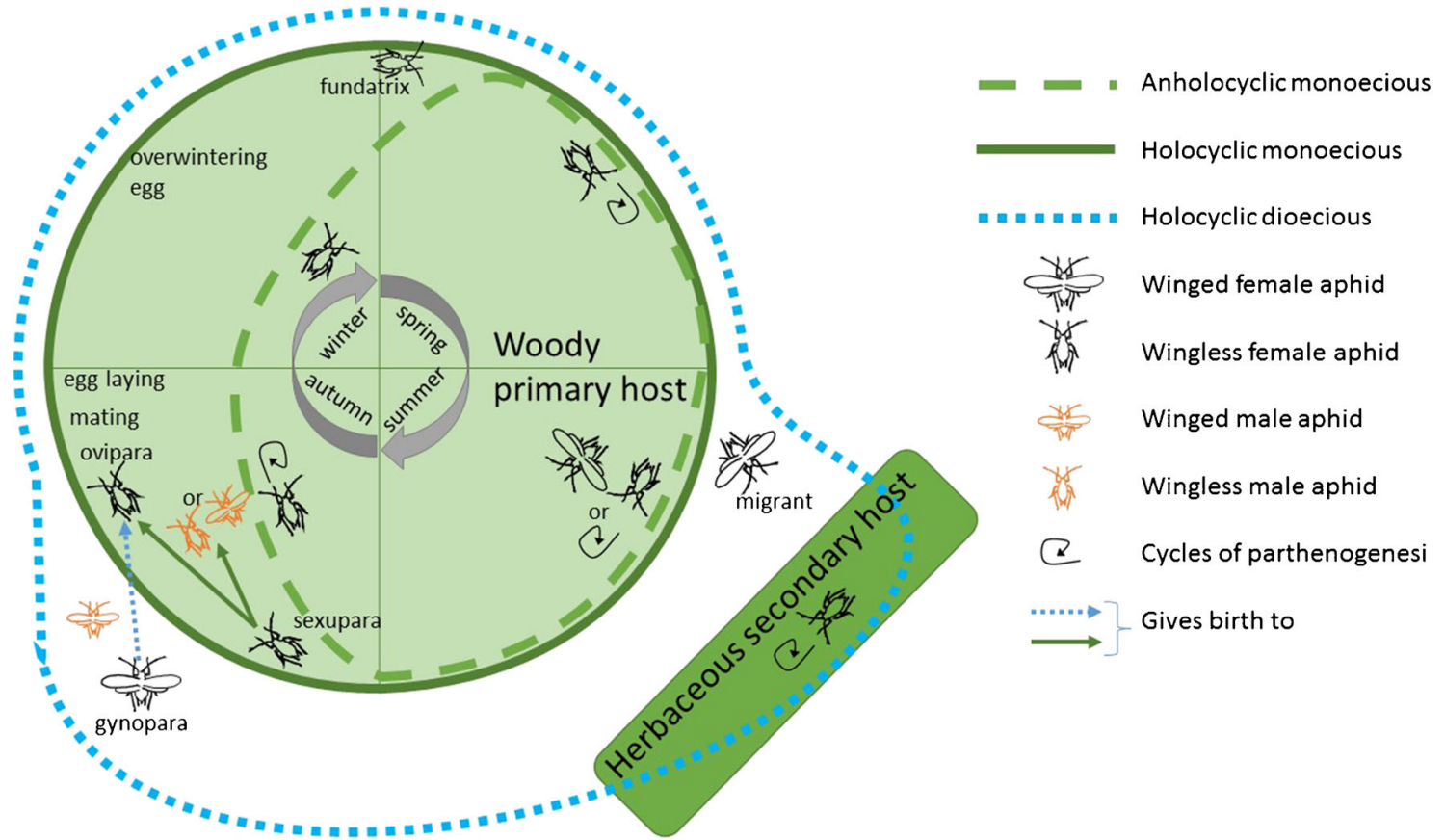

Fig. 2 Variants of fruit tree aphid life cycle. In spring, aphids undergo asexual reproduction on their woody host. In summer, monoecious species stay on the woody host while dioecious species fly to their secondary host. In autumn, dioecious species fly back to their woody

host. Holocyclic species undergo sexual reproduction and oviparae lay overwintering eggs whereas anholocyclic species overwinter as wingless females

et al. 1995; Carisse and Jobin 2006) are temperature dependant, i.e. rely on degree-day accumulation above a threshold below which development stops. So, genetic avoidance usually means that a higher threshold delays the plants' development with respect to the insects' requirements.

\subsubsection{Top-down}

The top-down processes acting at the egg hatching stage are the same as the ones detailed in the section below. However, it should be emphasised that the efficiency of top-down control
Table 1 Life cycle characteristics and host use of the main aphid species of apple and peach trees in European orchards

\begin{tabular}{llll}
\hline & Life cycle & Host & Sources \\
\hline $\begin{array}{l}\text { Apple tree, Malus domestica Borkh. } \\
\text { Aphis pomi De Geer }\end{array}$ & H & M & Hullé et al. 2006 \\
Aphis spiraecola Patch & A & M & Hullé et al. 2006 \\
Dysaphis plantaginea (Passerini) & H & D & Hullé et al. 2006 \\
Dysaphis devecta (Walker) & H & M & Ryan et al. 2015 \\
Eriosoma lanigerum (Hausmann) & A & M & Hullé et al. 2006 \\
Rhopalosiphum insertum (Walker) & H & D & Hullé et al. 2006 \\
Peach tree, Prunus persica (L.) Batsch & & & \\
Brachycaudus persicae Passerini & H & D & Hullé et al. 2006; Penvern et al. 2010 \\
Brachycaudus prunicola (Kaltenbach) & H & M & Penvern et al. 2010 \\
Brachycaudus schwartzi (Börner) & H & M & Hullé et al. 2006; Penvern et al. 2010 \\
Hyalopterus pruni (Geoffroy) & H & D & Hullé et al. 2006 \\
Myzus persicae Sulzer & H & D & Hullé et al. 2006; Penvern et al. 2010 \\
Myzus varians Davidson & H & D & Hullé et al. 2006; Penvern et al. 2010 \\
\hline
\end{tabular}

Life cycle: $A$ anholocyclic, $H$ holocyclic. Host: $D$ dioecious, $M$ monoecious 


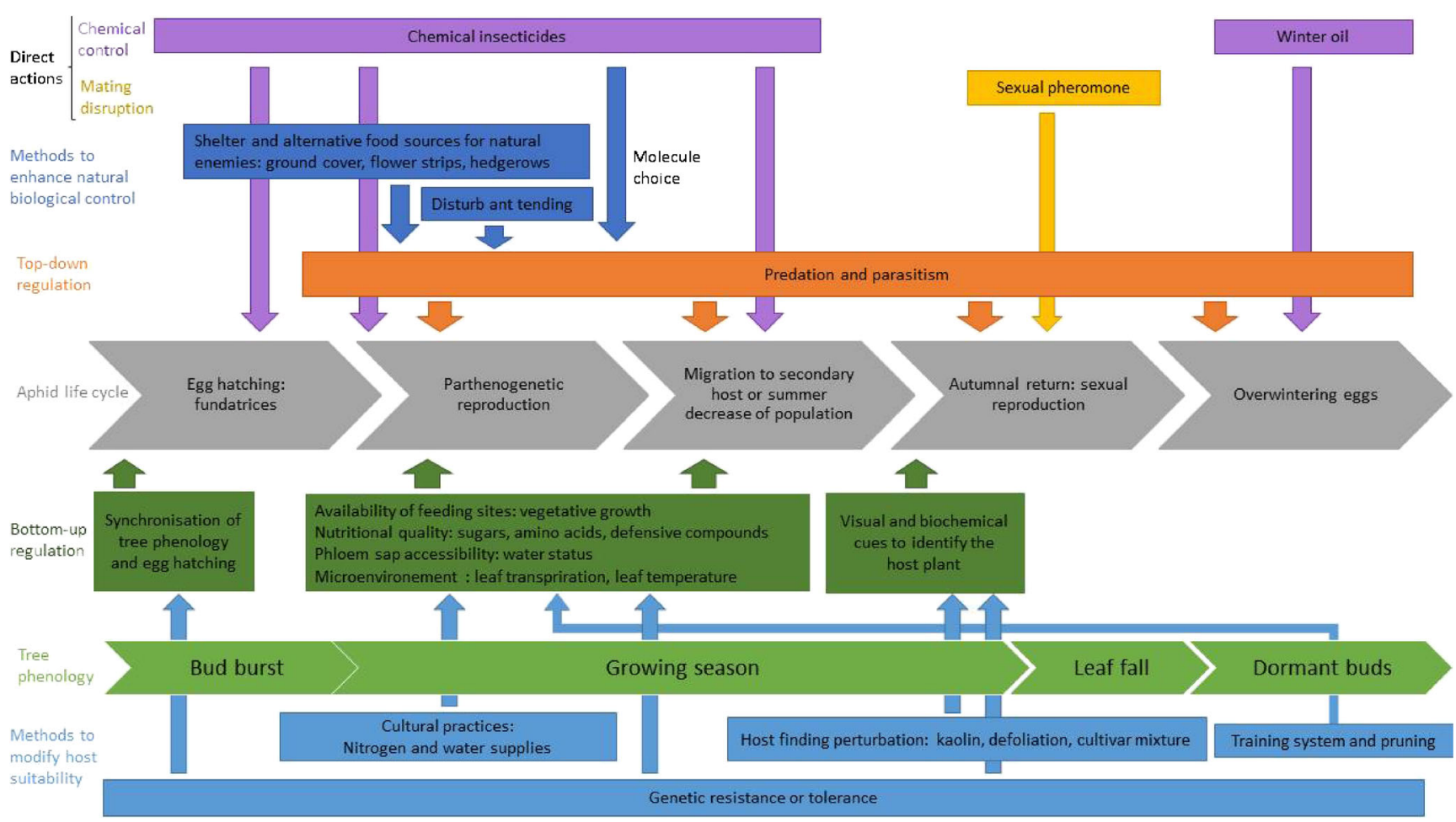

Fig. 3 Possible methods to control aphid populations in apple and peach orchards by mobilizing bottom-up and top-down processes

depends on the precocity of the action, due to the exponential increase of aphid populations. So, natural enemies that are active early in the season are of crucial importance (Wyss 1995; Stewart-Jones et al. 2008; Nagy et al. 2013).

\subsection{Parthenogenetic reproduction}

\subsubsection{Bottom-up}

Genetic resistance Genetic resistance can be separated into two categories: antixenosis resistance, which prevents plant colonisation, and antibiosis resistance, which alters pest development and/or reproduction (Sauge et al. 2006; Sauge et al. 2011). Genotypes can also be tolerant to aphids, meaning that they can bear abundant aphid populations without a strong negative impact on production or growth (Angeli and Simoni 2006).

In peach, cultivars resistant to $M$. persicae have been identified (Verdugo et al. 2016). 'Weeping Flower Peach' (Sauge et al. 2011) and 'Rubira' (Sauge et al. 1998, 2002, 2006; Pascal et al. 2002; Lambert and Pascal 2011) possess single dominant resistance genes, $\mathrm{Rm} 1$ and $\mathrm{Rm} 2$, respectively, conferring antixenosis resistance. The peach cultivars 'Malo konare' and 'Summergrand' and the related wild Prunus davidiana ((Carrière) Franch.) show antibiosis resistance. The resistance of $P$. davidiana is polygenic, i.e. located on seven QTLs (Sauge et al. 2011), and strongly reduces aphid fecundity (Sauge et al. 1998, 2011). 'Malo konare' and
'Summergrand' resistances increase aphid pre-reproductive development time (Sauge et al. 1998).

In apple, Stoeckli et al. (2008b) identified two QTLs for resistance to D. plantaginea and Dysaphis devecta (Walker, F.), respectively, and Bus et al. (2007) identified three major genes for resistance to Eriosoma lanigeru (Hausmann): $E r 1$ from 'Northern Spy', Er2 from 'Robusta' and Er3 from Malus sieboldii ((Regel ex Dippel) Rehder) 'Aotea 1'. As E. lanigerum also forms belowground colonies, it can also be relevant to use a resistant rootstock cultivar (Blommers 1994; Lordan et al. 2015). There are also three resistance genes to $D$. devecta: $S d-1$ from 'Cox's Orange Pippin', $S d-2$ from 'Northern Spy' and $S d-3$ from Malus robusta ((Carrière) Rheder) and Malus zumi ((Matsum) Rheder) (Alston and Briggs 1977; Cevik and King 2002). The cultivar 'Florina' combines tolerance, antixenosis and antibiosis mechanisms of resistance to D. plantaginea (Qubbaj et al. 2005; Angeli and Simoni 2006), with a strong surface repellence and a resistance factor in phloem sieve elements (Marchetti et al. 2009). The cultivar 'Golden Orange' also shows resistance to $D$. plantaginea with a strong antixenotic effect on preadult instars (Angeli and Simoni 2006).

The introduction of genetic resistance to aphids into commercial cultivars can help to reduce aphid pressure in orchards. However, this option should be considered with caution as E. lanigerum (Bus et al. 2007; Smith and Chuang 2014) and D. devecta (Smith and Chuang 2014) developed populations that were virulent to apple genotypes expressing 
monogenic resistance. Thus, to increase resistance durability, polygenic sources of resistance should be favoured over monogenic resistance (Lambert and Pascal 2011), even if it is more challenging to breed a cultivar with polygenic resistance (Smith and Chuang 2014) while maintaining interesting fruit quality characteristics.

Cultural practices to modify host plant suitability Host plant suitability for aphids encompasses several aspects, e.g. phloem sap nutritional quality and accessibility, and feeding site availability, which all can be manipulated by different cultural practices.

Phloem nutritional quality for aphids is mainly characterised by its provision of soluble amino acids and its $\mathrm{C} / \mathrm{N}$ ratio. Indeed, low nitrogen availability is a major constraint of phloem feeding (Bonnemain 2010). Therefore, nutrient inputs such as nitrogen fertilisation that increase plant content in amino acids can positively impact aphid populations (Kyto et al. 1996; Sauge et al. 2010). Water supply as well can modify the amino acid pool, as demonstrated for alfalfa (Girousse et al. 1996).

In addition, water supply can modify the physical properties of the phloem, namely turgor pressure, osmotic potential and sap viscosity (Ryan and Asao 2014; Sevanto 2014). Aphid performance on Dactylis glomerata (L.) has been shown to be negatively impacted by water soluble carbohydrate content (Alkhedir et al. 2013). As a moderate water restriction reduces plant growth but has no impact on photosynthesis (Mitchell et al. 2013), an increased sap viscosity resulting from increased carbohydrate contents and consequently a decreased phloem accessibility to aphids can be expected. The hypothesis of reduced phloem accessibility has been suggested to explain reduced aphid performance on water stressed apple and peach trees: $A$. pomi-apple tree (Mody et al. 2009) and M. persicae - peach tree (Rousselin et al. 2016).

For most aphid species, feeding site availability is related to the number and spatial organisation (i.e. connections) of the growing shoots, which are partly determined by the training system. In apple trees, for instance, the success of colony dispersal within the canopy is reduced by the complexity of tree branching for D. plantaginea (Simon et al. 2011b). M. persicae (Grechi et al. 2008) and A. pomi (Stoeckli et al. 2008a) performances were furthermore positively correlated to individual shoot growth, which could be modulated by pruning intensity, water and nutrient inputs. The negative effect of nitrogen restriction on the performance of $M$. persicae on peach has thus been shown to be mediated namely by a restriction of vegetative growth (Rousselin et al. 2016). Moreover, low pruning intensity reduces individual shoot elongation rate, as plant vigour is distributed across a higher number of shoots, which results in limited $M$. persicae infestation (Grechi et al. 2008).
Canopy microenvironment such as foliar leaf temperature is of prime importance for insect fitness. This environmental condition can be strongly impacted due to water stress or restriction, leading to stomatal closure (Pangga et al. 2012).

The combination and intensities of the cultural practices commonly used in commercial orchards affect the plant physiological status. Their final outcome on plant suitability is hardly predictable as favourable and unfavourable plant traits were simultaneously affected. Nonetheless, there is a consensus that the control of vegetative growth or nitrogen accumulation in growing shoots by pruning, adapted fruit load (Mediene et al. 2002; Bussi et al. 2010; Lauri et al. 2014), and by moderate water and nutrient inputs reduce the development of aphid colonies.

\subsubsection{Top-down}

Conservation biological control To foster natural enemy populations, different measures of habitat management have been implemented to provide shelter, substitution prey in periods of aphid scarcity on crop trees, and pollen and nectar (Dedryver et al. 2010; Simon et al. 2010; Markó and Keresztes 2014). Shelters can increase survival of natural enemies, which was shown, for example, for provision of hay mulch around tree trunks, which significantly increased the overwintering survival rate of Aphelinus mali (Haldeman), a parasitoid of E. lanigerum (Zhou et al. 2014). Other studies considered the possible effects of groundcover on the abundance of aphid natural enemies and aphids themselves. The results are contrasting, varying in relation to arthropod species actually occurring in orchard ecosystems, the initial aphid infestation severity, the cover plant species and the synchronicity between tree phenology and cover plant flowering. On the one hand, it has been shown that even if flowering alleys increase spider abundance in apple orchards compared to bare ground, there might be no effect on A. pomi aphid abundance (Markó and Keresztes 2014). In addition, extrafloral nectar sources decreased predation of Aphis spiraecola (Patch) by a Coccinellidae: Harmonia axyridis (Pallas) by providing alternative food resources (i.e. nectar) to the predator (Spellman et al. 2006). On the other hand, weed strips in apple orchards increase aphidophagous predator abundance (e.g. Araneae, Cecidomyiidae, Chrysopidae, Heteroptera) and reduce D. plantaginea aphid abundance (Wyss et al. 1995). Consistently, the addition of sweet alyssum (Lobularia maritima (L.)) caused a decrease in E. lanigerum abundance due to increased abundance of natural enemies (e.g. spiders and Anthocoridae) that switch between the flowers and the tree canopy (Gontijo et al. 2013). In the context of conservation biological control, it seems noteworthy that fostering the whole complex of natural enemies is more promising to reach sustainable biological control than just supporting single natural enemy species. For example, the coaction of different 
predator and parasitoid species was shown to provide complementary control of E. lanigerum in an apple orchard (Gontijo et al. 2015). Another study showed temporal complementarity between earwigs, acting in spring, and A. mali, acting in summer and fall for control of E. lanigerum (Lordan et al. 2015). Although not yet shown for aphids, different enemy species may provide complementary pest control on different fruit tree cultivars in the same orchard (Mody et al. 2017).

The limitation of insecticide use (Brown 2008; Dedryver et al. 2010) and the choice of selective molecules less harmful to natural enemies (Gentz et al. 2010) can help to foster natural enemy populations, especially for species particularly sensitive to broad-spectrum insecticides such as parasitoids (Cross et al. 1999). A comparative study showed lower D. plantaginea abundance and higher natural enemy abundance in organic orchards than in conventional and integrated pest management (IPM) orchards. The authors suggest that the biocontrol of aphids has been disrupted in IPM and conventional orchards by chemical insecticides (Dib et al. 2016b).

To favour natural enemy populations and action, it can be relevant for control of some aphid species to disrupt aphid tending by ants. Ants may benefit from aphid honeydew and, in exchange, provide protection of aphids against natural enemies and increase colony hygiene (Stewart-Jones et al. 2008; Nagy et al. 2013). Preventing ants from climbing into the tree canopy by using sticky barriers reduced population size of $D$. plantaginea and also aphid-related damage to harvested fruits (Stewart-Jones et al. 2008). However, this method has many drawbacks, including the exclusion of crawling predators such as earwigs from the tree canopy and the need for labour-intensive regular application and control of sticky barriers. It also implies a strict management of row vegetation. It is therefore not applicable in large commercial orchards (Nagy et al. 2013). An alternative method consists in providing alternative carbohydrate sources to the ants, by the positioning of feeders with a sucrose solution on the trunk base. The set-up of such feeders in apple orchards proved to be as efficient as the traditional ant-exclusion technique for D. plantaginea control (Nagy et al. 2015).

Finally, the proliferation of biocontrol agents could be favoured: first, reconsidering the chemicals used for phytoprotection and second, adapting alternative methods, such as weed strips or ant feeding to the local biotic environment

Releases of biological control agents Entomopathogenic fungi can infest and kill individual aphids and so can cause colony collapse (Zhou and Feng 2010). The virulence of several species of fungi on $M$. persicae has been demonstrated in the laboratory: Metarhizum (Sorokin) strains (Shan and Feng 2010; Jandricic et al. 2014), Purpureocillium lilacinum (Jones and Samson) (Lee et al. 2015) and Beauvaria bassiana ((Bals.-Criv) Vuill.) strains (Jandricic et al. 2014). The main obstacle to overcome for an efficient use of fungi for aphid management in orchards is the adaptation of the fungus strains to the field conditions. A strong virulence is not sufficient for biocontrol purposes, the strains need also to be thermo- and UV-B-tolerant (Lee et al. 2015). The adequate formulation to preserve sporulation capacities has to be found (Zhou and Feng 2010). For aphids living in rolled leaves such as $D$. plantaginea, the efficient application of fungal spores for biocontrol can be arduous, so the use of Lasius niger (Linnaeus) ants as passive vector of the spores has been considered and resulted in infestation of aphid colonies (Bird et al. 2004). The use of entomopathogenic nematodes for aphid control has also been studied, but the results are not encouraging, with a low infectivity of the tested nematodes (Park et al. 2013; Berkvens et al. 2014).

Biological control by augmentation through releases of natural aphid enemies is not included in common orchard practices. The release of earwigs seems not to affect the abundance of $D$. plantaginea (Dib et al. 2016a). On the contrary, the release of larvae of Adalia bipunctata (Linnaeus) (i.e. a Coccinellidae) early in the season helps to achieve control of D. plantaginea populations. However, the effect has been obtained with a predator:prey ratio of 1:1 or 5:1 (Wyss et al. 1999), compromising the cost-efficiency of the method. So, further studies are needed, possibly exploiting codling moth exclusion nets, which are of extended use due to their side effects on fruit quality and orchard microclimate (Lloyd et al. 2005; Baiamonte et al. 2016), as a physical barrier to increase the efficiency of the releases (Dib et al. 2016a). Mummified aphids were found to be more efficient to release Aphidius ervi (Haliday) than adult parasitoids (Wei et al. 2005).

So, even if release methods are promising, they still face technical problems regarding their adaptation for aphid control in commercial orchards. Those technical issues need to be solved to allow large scale use of release methods.

\subsection{Autumnal return (dioecious species)}

\subsubsection{Bottom-up: impairing host plant location and decreasing host plant suitability}

Repeated autumn applications of kaolin have been shown to decrease the landing and larvae deposition of gynoparae of D. plantaginea on apple trees (Bürgel et al. 2005). The repeated treatments either suppress aphid populations in the following spring (Andreev et al. 2012) or reduce it, but not below economic threshold levels (Bürgel et al. 2005). The potential mechanisms underlying these effects are perturbation of visual and physical cues to recognise the host plant, and a limitation of aphid movement, feeding and oviposition on treated trees (Bürgel et al. 2005). Kaolin has also been tested in spring but yielded contradictory results. In an apple orchard, the aphid 
abundances decreased after repeated spring application for $A$. pomi and increased for D. plantaginea and E. lanigerum. These results might be explained by a reduction of ant attendance on A. pomi and a lower efficiency of the natural enemies for the two other aphid species (Markó et al. 2008). Because of these contradictory results, kaolin should be used only in autumn to prevent aphid return.

Manual artificial defoliation in September or early October results in aphid absence in the following spring (Andreev et al. 2012). The possible mechanisms underlying this effect are that aphids fail to recognise their host plant in the absence of leaves or that autumnal aphids are unable to settle on leafless apple trees. This method seems promising; however, the effect of defoliation on tree reserves remains to be assessed, especially if this technique is to be repeated on a yearly basis.

Water restriction, suggested as a bottom-up method to reduce spring aphid populations, can postpone autumnal leaf senescence (Naschitz et al. 2014). Depending on the host plant and the aphid species considered, this delayed senescence can have contrasting effects. For the Prunus padus (L.) - Rhopalosiphum padi (Linnaeus) system, it has been found that aphid autumnal return is positively influenced by green leaves (Archetti and Leather 2005). On the contrary, early leaf senescence increases the number of overwintering eggs of Euceraphis betulae (Koch) on Betula pendula (Roth) in short autumn (Silfver et al. 2014).

Cultivar mixtures of apple trees with differential resistance to $D$. plantaginea has been shown to reduce aphid incidence on the susceptible cultivar compared to a pure stand of the susceptible cultivar. This positive effect of cultivar mixture has been attributed to a dilution effect of the resource, which is the susceptible cultivar (Parisi et al. 2013).

\subsubsection{Direct action: use of sexual pheromone lures to impair mating partner location and reduction of aphid inoculum}

During the sexual generation involving oviparae and winged males, oviparae release a sex pheromone to guide conspecific males. The two pheromone components $(4 \mathrm{aS}, 7 \mathrm{~S}, 7 \mathrm{aR})-$ nepetalactone and $(1 \mathrm{R}, 4 \mathrm{aS}, 7 \mathrm{~S}, 7 \mathrm{aR})$-nepetalactol are quite common among aphid species; however, it is the ratio between the two components which is species specific (Symmes et al. 2012). These sex pheromones could be used to monitor fall populations and also to disrupt mating (Boo et al. 2000; Symmes et al. 2012). A 1:1 ratio of the two components of the sex pheromone has been shown to be efficient to trap Hyalopterus pruni (Goeffroy) and Brachycaudus helichrysi (Kaltenbach) in prune orchards (Prunus domestica (L.)). However, the trap has also caught an important proportion of non-target aphid species, so the bait should be improved if it is to be used for monitoring purposes (Symmes et al. 2012). For Tuberocephalus momonis (Matsumara) in peach orchards, the best performing blend of the pheromone components was 85:15 (Boo et al. 2000).

As dioecious aphid species spend the summer season on secondary hosts, the removal of those plants in the orchards and their vicinity might theoretically limit the autumnal return. However, this strategy is unrealistic for aphid species whose secondary hosts are too numerous (e.g. more than 400 for M. persicae (Bass et al. 2014)) or which are too mobile to be strongly affected by secondary host removal since their return flight likely covers long distances (e.g $D$. plantaginea (Guillemaud et al. 2011)). For aphid species with a restricted secondary host plant range, such as Hyalopterus pruni (Geoffroy) - Phragmites (Adans) spp. or Myzus varians (Davidson)_Clematis (L.) spp., further investigations are needed before implementing host removal, as this practice may be rather time consuming and negatively related to other activities aiming at biodiversity conservation in the orchard vicinity.

\subsubsection{Top-down: web-building spiders}

Whereas some aphidophagous insects have been shown to be relatively inactive in autumn, web-building spiders have been observed in relevant quantity in an apple orchard (Wyss 1995). The finding that the number of spider webs in autumn is negatively correlated with aphid abundance in subsequent spring suggests that measures that increase spider abundance in orchards such as weed strips could help to reduce orchard infestation by winged aphids returning in autumn.

\subsection{Overwintering forms}

Studies focusing on alternatives to chemicals for control of overwintering aphid stages are scarce. E. lanigerum aphids overwinter as apterous females either on the roots or within the canopy of apple trees. Overwintering canopy colonies of E. lanigerum can be strongly reduced by earwigs, so any measure to favour earwig can have a positive effect on the control of this aphid (Lordan et al. 2015). Earwigs as natural enemies of aphids are considered in most studies to be beneficial for apple production (Dib et al. 2010b; Cross et al. 2015); however, as they can also damage fruits, they are sometimes considered as apple pest (Markó et al. 2008) and most of the time classified as peach pest (Saladini et al. 2016).

\section{Side effects of alternative methods to chemicals for aphid control}

\subsection{Orchard pest community complexity}

The implementation of alternative control methods for aphid management - such as modified host plant suitability or 
environment - can have contrasting effects on other orchard pathogens or pests. These effects can be arduous to predict as the implementation of alternative methods can cause changes in both pest and natural enemy communities. Indeed, it has been observed in Southern France that a higher number of aphid species colonise peach trees in orchards that are less intensively treated with pesticides (Penvern et al. 2010).

For example, a tree cultivar selected to be resistant to a specific pest can be susceptible to another one. The peach cultivar 'Rubira' is resistant to $M$. persicae but susceptible to Brachycaudus persicae (Passerini) (Sauge et al. 1998; Sauge et al. 2002). Similarly, the apple cultivar 'Florina' is resistant to D. plantaginea and to scab (Miñarro and Dapena 2008), but susceptible to E. lanigerum (Abu-Romman and Ateyyat 2014). Deficit irrigation seems to reduce peach tree susceptibility to aphids and has also a positive effect on the control of brown rot. This effect of water restriction on brown rot might be due to a reduction of microcracks on the fruit surface, which limits the invasion of pathogens (Mercier et al. 2008). On the contrary, egg hatching of the buprestid Capnodis tenebrionis (Linnaeus) can be compromised by high soil humidity, so restrictive irrigation might have a positive effect on this stone orchard pest (Marannino and De Lillo 2007). The cultivar mixture of apple cultivars varying in their resistance to scab results in decreased scab and $D$. plantaginea infestations on the susceptible cultivar (Parisi et al. 2013). Ground cover management, which is suggested to positively influence biological control of aphids, may also increase vole (Microtus savii (De Selys-Longchamps)) populations (Bertolino et al. 2014). As the effects of the alternative methods implemented for aphid management can be either positive or negative depending on their effects on other pest species, they should be selected and combined according to locally important pest species to optimise the control of the orchard pest community. In this context, it is noteworthy that the implementation of alternative control methods for the management of other pests can also impact aphid dynamics. Indeed, codling moth exclusion nets closed in April during aphid development have been shown to decrease D. plantaginea abundance (Dib et al. 2010a).

\subsection{Fruit production and quality}

Innovative methods for aphid management can impact fruit yield and quality. Therefore, the implementation of alternatives to chemicals needs to consider also the production of marketable fruits, which is the farmer's ultimate goal. That means taking into account all aspects of profitability, i.e. yield (fruit number and weight) and quality (fruit size, colour and sweetness).

Nitrogen restriction can impact yield, as demonstrated in apple orchards (Kühn et al. 2011). Water restriction has contrasting effects on fruit production and quality depending on its time of application and intensity. It can either reduce yield (Naor et al. 1999, 2001; Girona et al. 2010) or have no effect (Mercier et al. 2008). However, economic losses related to lower yield may be compensated by higher fruit quality. Indeed, deficit irrigation may decrease peach fruit diameter (Mercier et al. 2008; Rahmati et al. 2015), but increase fruit softness (Mercier et al. 2008) and sugar content (Mercier et al. 2008; Rahmati et al. 2015). The economic valorisation could thus counterbalance the yield reduction as informed consumers are willing to pay more for fruits produced with less chemicals (Marette et al. 2012).

\section{Conclusion}

This study aims to identify the possible levers for the control of aphid populations in relation with plant phenology and insect life cycle (Fig. 3). This integrative approach is, to our knowledge, quite new and favours the design of long-term control strategies adapted to local scale taking into account climate, soil properties, tree physiological status, and the arthropod (pests and natural enemies) community. Indeed, most of the cultural practices, for example, training systems, regulated deficit irrigation and flower strips, that might be applied for controlling aphid abundance in peach and apple orchards, modify the overall tree functioning and the trees' surroundings for a long period, and their effects could also be delayed and time-varying. They can thus not be used in response to an acute infestation event but have to be integrated in a longterm strategy. Bottom-up processes, which aim, for instance, to decrease plant suitability, need to be initiated before aphid outbreaks. Top-down control, on the other hand, can be limited in case of rapid and severe infestation (Wyss et al. 1995). Aphid outbreaks under favourable conditions can justify the use of chemicals as a last resort to solve inextricable situations. The choice of an adapted strategy is therefore a rather complex process, which has to take into account other main determinants of horticultural production, such as profitability, labour requests and maintenance of orchard productivity over time. It has also to be adapted to the local conditions.

The benefits of using alternative strategies could hardly be evaluated, and it is therefore difficult to determine relevant economic thresholds for the implementation of the alternative. Thus, the yield loss, the costs of the those methods compared to chemicals and the potentially increased value of the more environmentally friendly fruits were almost never considered. Indeed, most studies have focused on aphid abundance not on aphid damage. Moreover, as aphids impair vegetative growth, and therefore the number and the quality of buds that may develop the following spring, the repercussion of aphid abundance in 1 year should be assessed, not only on current-year yield but also on production potential of the following years. 
Acknowledgments This work was funded by the ARIMNET (ANR12-AGR-0001) 'APMed' (Apple and Peach in Mediterranean orchards) and by the ONEMA-ECOPHYTO ( $3{ }^{\text {ème }}$ APR Résistance et Pesticides) 'RegPuc' (Quelles strategies d'irrigation et de fertilisation pour réguler les populations de pucerons vert en vergers de pêcher) projects. The PACA region (Provence-Alpes-Côtes d'Azur) and INRA funded the PhD grant of A. Rousselin.

\section{References}

Abu-Romman S, Ateyyat M (2014) Phenotypic and molecular screening of apple genotypes to woolly apple aphid resistance. Not Bot Horti Agrobo 42:99-103

Alkhedir H, Karlovsky P, Vidal S (2013) Relationship between water soluble carbohydrate content, aphid endosymbionts and clonal performance of Sitobion avenae on cocksfoot cultivars. PLoS One 8: e54327. doi:10.1371/journal.pone.0054327

Alston FH, Briggs JB (1977) Resistance genes in apple and biotypes of Dysaphis devecta. Ann Appl Biol 87:75-81. doi:10.1111/j.17447348.1977.tb00661.x

Andreev R, Kutinkova H, Rasheva D (2012) Non-chemical control of Aphis spiraecola Patch. and Dysaphis plantaginea pass. on apple. $\mathrm{J}$ Biopest 5:239-242

Angeli G, Simoni S (2006) Apple cultivars acceptance by Dysaphis plantaginea Passerini (Homoptera: Aphididae). J Pest Sci 79:175179. doi:10.1007/s10340-006-0129-6

Archetti M, Leather SR (2005) A test of the coevolution theory of autumn colours: colour preference of Rhopalosiphum padi on Prunus padus. Oikos 110:339-343. doi:10.1111/j.0030-1299.2005.13656.x

Baiamonte I, Raffo A, Nardo N, Moneta E, Peparaio M, D'aloise A, Kelderer M, Casera C, Paoletti F (2016) Effect of the use of antihail nets on codling moth (Cydia pomonella) and organoleptic quality of apple (cv. Braeburn) grown in Alto Adige Region (northern Italy). J Sci Food Agric 96:2025-2032. doi:10.1002/jsfa.7313

Barbagallo S, Cocuzza G, Cravedi P, Komazaki S (2007) IPM case studies: deciduous fruit trees. In: Harrington R (ed) Van Emden HF. CABI, Aphids as crop pests, pp 651-661. doi:10.1079/ 9780851998190.0651

Bass C, Puinean AM, Zimmer CT, Denholm I, Field LM, Foster SP, Gutbrod O, Nauen R, Slater R, Williamson MS (2014) The evolution of insecticide resistance in the peach potato aphid, Myzus persicae. Insect Biochem Mol Biol 51:41-51. doi:10.1016/j.ibmb. 2014.05.003

Berkvens N, Van Vaerenbergh J, Maes M, Beliën T, Viaene N (2014) Entomopathogenic nematodes fail to parasitize the woolly apple aphid Eriosoma lanigerum as their symbiotic bacteria are suppressed. J Appl Entomol 138:644-655. doi:10.1111/jen.12117

Bertolino S, Asteggiano L, Saladini MA, Giordani L, Vittone G, Alma A (2014) Environmental factors and agronomic practices associated with Savi's pine vole abundance in Italian apple orchards. J Pest Sci 88:135-142. doi:10.1007/s10340-014-0581-7

Bevacqua D, Grechi I, Génard M, Lescourret F (2016) The consequences of aphid infestation on fruit production become evident in a multiyear perspective: insights from a virtual experiment. Ecol Model 338:11-16. doi:10.1016/j.ecolmodel.2016.07.022

Bird AE, Hesketh H, Cross JV, Copland M (2004) The common black ant, Lasius niger (Hymenoptera: Formicidae), as a vector of the entomopathogen Lecanicillium longisporum to rosy apple aphid, Dysaphis plantaginea (Homoptera: Aphididae). Biocontrol Sci Tech 14:757-767. doi:10.1080/09583150410001720716

Blommers LHM (1994) Integrated pest management in European apple orchards. Annu Rev Entomol 39:213-241
Bonnemain JL (2010) Aphids as biological models and agricultural pests. C R Biol 333:461-463. doi:10.1016/j.crvi.2010.04.002

Boo KS, Choi MY, Chung IB, Eastop VF, Pickett JA, Wadhams LJ, Woodcock CM (2000) Sex pheromone of the peach aphid Tuberocephalus momonis, and optimal blends for trapping males and females in the field. J Chem Ecol 26:601-609. doi:10.1023/A: 1005415919226

Brown MW (2008) Sustainable biocontrol of apple insect pests. Pest Technol 2:98-103

Bürgel K, Daniel C, Wyss E (2005) Effects of autumn kaolin treatments on the rosy apple aphid, Dysaphis plantaginea (Pass.) and possible modes of action. J Appl Entomol 129:311-314. doi:10.1111/j.14390418.2005.00968.311-314

Bus VGM, Chagné D, Bassett HCM, Bowatte D, Calenge F, Celton JM, Durel CE, Malone MT, Patocchi A, Ranatunga AC, Rikkerink EHA, Tustin DS, Zhou J, Gardiner SE (2007) Genome mapping of three major resistance genes to woolly apple aphid (Eriosoma lanigerum Hausm.) Tree Genet Genomes 4:223-236. doi:10.1007/s11295007-0103-3

Bussi C, Lescourret F, Mercier V, Génard M (2010) Effects of winter pruning and of water restriction on fruit and vegetative growth, water potential and leaf gas exchange during the final stage of rapid growth in an early maturing peach cultivar. Eur J Hort Sci 75:15-19

Carisse O, Jobin T (2006) Development of a degree-day model for predicting apple leaf emergence during the primary scab period for timing of fungicide sprays. Can J Plant Pathol 28:345-346

Cevik V, King J (2002) High-resolution genetic analysis of the Sd-1 aphid resistance locus in Malus spp. Theor Appl Genet 105:346-354. doi: 10.1007/s00122-002-0904-6

Costes E, Lauri PE, Simon S, Andrieu B (2012) Plant architecture, its diversity and manipulation in agronomic conditions, in relation with pest and pathogen attacks. Eur J Plant Pathol 135:455-470. doi:10. 1007/s10658-012-0158-3

Cross J, Fountain M, MarkÓ V, Nagy C (2015) Arthropod ecosystem services in apple orchards and their economic benefits. Ecol Entomol 40:82-96. doi:10.1111/een.12234

Cross JV, Solomon MG, Babandreier D, Blommers LHM, Easter Brook MA, Jay CN, Jenser G, Jolly RL, Kuhlmann U, Lilley R, Olivella E, Toepfer S, Vidal S (1999) Biocontrol of pests of apples and pears in northern and central Europe: 2. Parasitoids. Biocontrol Sci Tech 9: 277-314. doi:10.1080/09583159929569

Czerniewicz P, Leszczynski B, Chrzanowski G, Sempruch C, Sytykiewicz H (2011) Effects of host plant phenolics on spring migration of bird cherry-oat aphid (Rhopalosiphum padi L.) Allelopathy J 27:309-316

Dapena E, Miñarro M (2001) Evaluation of the tolerance to the rosy apple aphid, Dysaphis plantaginea (Pass.) in descendants of the crossing 'Raxao' × 'Florina'. IOBC/wprs Bull 24:247-251

De Berardinis E, Baronio P, Baumgärtner J (1994) The effect of aphid (Dysaphis plantaginea Pass., Hom., Aphididae) feeding on apple fruit growth. Ecol Model 72:115-127. doi:10.1016/0304-3800(94) 90147-3

Dedryver CA, Le Ralec A, Fabre F (2010) The conflicting relationships between aphids and men: a review of aphid damage and control strategies. C R Biol 333:539-553. doi:10.1016/j.crvi.2010.03.009

Delorme R, Ayala V, Touton P, Augé D, Vergnet C (1999) Le puceron cendré du pommier (Dysaphis plantaginea): Etude des mécanismes de résistance à divers insecticides. In: ANPP PF (ed) Cinquième conférence internationale sur les ravageurs, Montpellier (France), pp 89-97

Dib H, Jamont M, Sauphanor B, Capowiez Y (2016a) The feasibility and efficacy of early-season releases of a generalist predator (Forficula auricularia L.) to control populations of the RAA (Dysaphis plantaginea Passerini) in Southeastern France. Bull Etomol Res 106:233-241. doi:10.1017/S0007485315001042 
Dib H, Sauphanor B, Capowiez Y (2010a) Effect of codling moth exclusion nets on the rosy apple aphid, Dysaphis plantaginea, and its control by natural enemies. Crop Prot 29:1502-1513. doi:10.1016/ j.cropro.2010.08.012

Dib H, Sauphanor B, Capowiez Y (2016b) Effect of management strategies on arthropod communities in the colonies of rosy apple aphid, Dysaphis plantaginea Passerini (Hemiptera: Aphididae) in southeastern France. Agric Ecosyst Environ 216:203-206. doi:10.1016/ j.agee.2015.10.003

Dib H, Simon S, Sauphanor B, Capowiez Y (2010b) The role of natural enemies on the population dynamics of the rosy apple aphid, Dysaphis plantaginea Passerini (Hemiptera: Aphididae) in organic apple orchards in south-eastern France. Biol Control 55:97-109. doi:10.1016/j.biocontrol.2010.07.005

FAO (2016) FAOstat Crops production data 2013. http://faostat3.fao.org/ download/Q/QC/E

Filajdić N, Sutton TB, Walgenbach JF, Unrath CR (1995) The influence of the apple aphid/spirea aphid complex on intensity of alternaria blotch of apple and fruit characteristics and yield. Plant Dis 79:691694

Garzón A, Medina P, Amor F, Viñuela E, Budia F (2015) Toxicity and sublethal effects of six insecticides to last instar larvae and adults of the biocontrol agents Chrysoperla carnea (Stephens) (Neuroptera: Chrysopidae) and Adalia bipunctata (L.) (Coleoptera: Coccinellidae). Chemosphere 132:87-93. doi:10.1016/j. chemosphere.2015.03.016

Gentz MC, Murdoch G, King GF (2010) Tandem use of selective insecticides and natural enemies for effective, reduced-risk pest management. Biol Control 52:208-215. doi:10.1016/j.biocontrol.2009.07. 012

Girona J, Behboudian MH, Mata M, Del Campo J, Marsal J (2010) Exploring six reduced irrigation options under water shortage for 'Golden Smoothee' apple: responses of yield components over three years. Agric Water Manag 98:370-375. doi:10.1016/j.agwat.2010. 09.011

Girousse C, Bournoville R, Bonnemain JL (1996) Water deficit-induced changes in concentrations in proline and some other amino acids in the phloem sap of alfalfa. Plant Physiol 111:109-103

Gontijo LM, Beers EH, Snyder WE (2013) Flowers promote aphid suppression in apple orchards. Biol Control 66:8-15. doi:10.1016/j. biocontrol.2013.03.007

Gontijo LM, Beers EH, Snyder WE (2015) Complementary suppression of aphids by predators and parasitoids. Biol Control 90:83-91. doi: 10.1016/j.biocontrol.2015.06.002

Grechi I, Sauge M-H, Sauphanor B, Hilgert N, Senoussi R, Lescourret F (2008) How does winter pruning affect peach tree-Myzus persicae interactions? Entomol Exp Appl 128:369-379. doi:10.1111/j.15707458.2008.00720.x

Guillemaud T, Blin A, Simon S, Morel K, Franck P (2011) Weak spatial and temporal population genetic structure in the rosy apple aphid, Dysaphis plantaginea, in French apple orchards. PLoS One 6: e21263. doi:10.1371/journal.pone.0021263

Hardy NB, Peterson DA, von Dohlen CD (2015) The evolution of life cycle complexity in aphids: ecological optimization or historical constraint? Evolution 69:1423-1432. doi:10.1111/evo.12643

Hopper KR (2003) United States Department of Agriculture-Agricultural Research Service research on biological control of arthropods. Pest Manag Sci 59:643-653. doi:10.1002/ps.707

Hullé M, Turpeau E, Chaubet B (2006) Encyclop'aphid. INRA https:// www6.inra.fr/encyclopedie-pucerons

Hunter MD, Price PW (1992) Playing chutes and ladders: heterogeneity and the relative roles of bottom-up and top-down forces in natural communities. Ecology 73:724-732

Jandricic SE, Filotas M, Sanderson JP, Wraight SP (2014) Pathogenicity of conidia-based preparations of entomopathogenic fungi against the greenhouse pest aphids Myzus persicae, Aphis gossypii, and
Aulacorthum solani (Hemiptera: Aphididae). J Invertebr Pathol 118:34-46. doi:10.1016/j.jip.2014.02.003

Karagounis C, Kourdoumbalos AK, Margaritopoulos JT, Nanos GD, Tsitsipis JA (2006) Organic farming-compatible insecticides against the aphid Myzus persicae (Sulzer) in peach orchards. J Appl Entomol 130:150-154. doi:10.1111/j.1439-0418.2006.01048.x

Kervella J, Pages L, Génard M (1995) Genotypic differences in the leaf emergence rate of young peach-trees. J Am Soc Hortic Sci 120:278282

Kühn BF, Bertelsen M, Sørensen L (2011) Optimising quality-parameters of apple cv. 'Pigeon' by adjustment of nitrogen. Sci Hortic 129:369375. doi:10.1016/j.scienta.2011.03.033

Kyto M, Niemela P, Larsson S (1996) Insects on trees: population and individual response to fertilization. Oikos 75:148-159. doi:10.2307/ 3546238

Lambert P, Pascal T (2011) Mapping Rm2 gene conferring resistance to the green peach aphid (Myzus persicae Sulzer) in the peach cultivar "Rubira®". Tree Genet Genomes 7:1057-1068. doi:10.1007/ s11295-011-0394-2

Lauri PE, Combe F, Brun L (2014) Regular bearing in the apple-architectural basis for an early diagnosis on the young tree. Sci Hortic 174:10-16. doi:10.1016/j.scienta.2014.05.001

Lee WW, Shin TY, Bae SM, Woo SD (2015) Screening and evaluation of entomopathogenic fungi against the green peach aphid, Myzus persicae, using multiple tools. J Asia Pac Entomol 18:607-615. doi:10.1016/j.aspen.2015.07.012

Lloyd A, Hamacek E, George A, Nissen R, Waite G (2005) Evaluation of exclusion netting for insect pest control and fruit quality enhancement in tree crops. In: drew R (ed) proceedings of the international symposium on harnessing the potential of horticulture in the AsianPacific region, 2005. Pp 253-258. Doi:10.17660/ActaHortic.2005. 694.41

Lordan J, Alegre S, Gatius F, Sarasua MJ, Alins G (2015) Woolly apple aphid Eriosoma lanigerum Hausmann ecology and its relationship with climatic variables and natural enemies in Mediterranean areas. Bull Etomol Res 105:60-69. doi:10.1017/S0007485314000753

Malagnoux L, Capowiez Y, Rault M (2015a) Impact of insecticide exposure on the predation activity of the European earwig Forficula auricularia. Environ Sci Pollut Res Int 22:14116-14126. doi:10. 1007/s11356-015-4520-9

Malagnoux L, Marliac G, Simon S, Rault M, Capowiez Y (2015b) Management strategies in apple orchards influence earwig community. Chemosphere 124:156-162. doi:10.1016/j.chemosphere.2014. 12.024

Marannino P, De Lillo E (2007) Capnodis tenebrionis (L. 1758) (Coleoptera: Buprestidae): morphology and behaviour of the neonate larvae, and soil humidity effects on the egg eclosion. Ann Soc Entomol FR 43:145-154. doi:10.1080/00379271.2007.10697504

Marchetti E, Civolani S, Leis M, Chicca M, Tjallingii WF, Pasqualini E, Baronio P (2009) Tissue location of resistance in apple to the rosy apple aphid established by electrical penetration graphs. Bull Insectol 62:203-208

Marette S, Messéan A, Millet G (2012) Consumers' willingness to pay for eco-friendly apples under different labels: evidences from a lab experiment. Food Policy 37:151-161. doi:10.1016/j.foodpol.2011. 12.001

Markó V, Blommers LHM, Bogya S, Helsen H (2008) Kaolin particle films suppress many apple pests, disrupt natural enemies and promote woolly apple aphid. J Appl Entomol 132:26-35. doi:10.1111/j. 1439-0418.2007.01233.x

Markó V, Keresztes B (2014) Flowers for better pest control? Ground cover plants enhance apple orchard spiders (Araneae), but not necessarily their impact on pests. Biocontrol Sci Tech 24:574-596. doi: 10.1080/09583157.2014.881981

Marliac G, Mazzia C, Pasquet A, Cornic J-F, Hedde M, Capowiez Y (2016) Management diversity within organic production influences 
epigeal spider communities in apple orchards. Agric Ecosyst Environ 216:73-81. doi:10.1016/j.agee.2015.09.026

Mediene S, Jordan MO, Pages L, Le Bot J, Adamowicz S (2002) The influence of severe shoot pruning on growth, carbon and nitrogen status in young peach trees (Prunus persica). Tree Physiol 22:1289 1296

Mercier V, Bussi C, Plenet D, Lescourret F (2008) Effects of limiting irrigation and of manual pruning on brown rot incidence in peach. Crop Prot 27:678-688. doi:10.1016/j.cropro.2007.09.013

Miñarro M, Dapena E (2007) Resistance of apple cultivars to Dysaphis plantaginea (Hemiptera: Aphididae): role of tree phenology in infestation avoidance. Environ Entomol 36:1206-1211. doi:10.1603/ 0046-225X(2007)36[1206:ROACTD]2.0.CO;2

Miñarro M, Dapena E (2008) Tolerance of some scab-resistant apple cultivars to the rosy apple aphid, Dysaphis plantaginea. Crop Prot 27:391-395. doi:10.1016/j.cropro.2007.07.003

Mitchell PJ, Battaglia M, Pinkard EA (2013) Counting the costs of multiple stressors: is the whole greater than the sum of the parts? Tree Physiol 33:447-450. doi:10.1093/treephys/tpt031

Mody K, Eichenberger D, Dorn S (2009) Stress magnitude matters: different intensities of pulsed water stress produce non-monotonic resistance responses of host plants to insect herbivores. Ecol Entomol 34:133-143. doi:10.1111/j.1365-2311.2008.01053.x

Mody K, Collatz J, Bucharova A, Dorn S (2017) Crop cultivar affects performance of herbivore enemies and may trigger enhanced pest control by coaction of different parasitoid species. Agric Ecosyst Environ 245:74-82. doi:10.1016/j.agee.2017.05.009

Moran NA (1992) The evolution of aphid life cycles. Annu Rev Entomol 37:321-348. doi:10.1146/annurev.en.37.010192.001541

Nagy C, Cross JV, Markó V (2013) Sugar feeding of the common black ant, Lasius niger (L.), as a possible indirect method for reducing aphid populations on apple by disturbing ant-aphid mutualism. Biol Control 65:24-36. doi:10.1016/j.biocontrol.2013.01.005

Nagy C, Cross JV, Markó V (2015) Can artificial nectaries outcompete aphids in ant-aphid mutualism? Applying artificial sugar sources for ants to support better biological control of rosy apple aphid, Dysaphis plantaginea Passerini in apple orchards. Crop Prot 77: 127-138. doi:10.1016/j.cropro.2015.07.015

Naor A, Hupert H, Greenblat Y, Peres M, Kaufman A, Klein I (2001) The response of nectarine fruit size and midday stem water potential to irrigation level in stage III and crop load. J Am Soc Hortic Sci 126: 140-143

Naor A, Klein I, Hupert H, Grinblat Y, Peres M, Kaufman A (1999) Water stress and crop level interactions in relation to nectarine yield, fruit size distribution, and water potentials. J Am Soc Hortic Sci 124: 189-193

Naschitz S, Naor A, Wolf S, Goldschmidt EE (2014) The effects of temperature and drought on autumnal senescence and leaf shed in apple under warm, east Mediterranean climate. Trees 28:879-890. doi:10.1007/s00468-014-1001-6

Nematollahi MR, Fathipour Y, Talebi AA, Karimzadeh J, Zalucki MP (2016) Comparison of degree-day distribution models for predicting emergence of the cabbage aphid on canola. Crop Prot 80:138-143. doi:10.1016/j.cropro.2015.11.011

Pangga IB, Hanan J, Chakraborty S (2012) Climate change impacts on plant canopy architecture: implications for pest and pathogen management. Eur J Plant Pathol 135:595-610. doi:10.1007/s10658-0120118-y

Panini M, Anaclerio M, Puggioni V, Stagnati L, Nauen R, Mazzoni E (2015) Presence and impact of allelic variations of two alternative $s$ $k d r$ mutations, M918T and M918L, in the voltage-gated sodium channel of the green peach aphid Myzus persicae. Pest Manag Sci 71:878-884. doi:10.1002/ps.3927

Parisi L, Gros C, Combe F, Parveaud C-E, Gomez C, Brun L (2013) Impact of a cultivar mixture on scab, powdery mildew and rosy aphid in an organic apple orchard. Crop Prot 43:207-212. doi:10. 1016/j.cropro.2012.09.014

Park HW, Kim HH, Cho MR, Kang TJ, Ahn S-J, Jeon SW, Choo HY (2013) Infectivity of entomopathogenic nematode Steinernema carpocapsae Pocheon strain (Nematoda: Steinernematidae) on the green peach aphid Myzus persicae (Hemiptera: Aphididae) and its parasitoids. Biocontrol Sci Tech 23:637-645. doi:10.1080/ 09583157.2013.786022

Pascal T, Pfeiffer F, Kervella J, Lacroze J-P, Sauge MH (2002) Inheritance of green peach aphid resistance in the peach cultivar 'Rubira'. Plant Breed 121:459-461. doi:10.1046/j.1439-0523.2002.734333.x

Penvern S, Bellon S, Fauriel J, Sauphanor B (2010) Peach orchard protection strategies and aphid communities: towards an integrated agroecosystem approach. Crop Prot 29:1148-1156. doi:10.1016/j. cropro.2010.06.010

Pruess KP (1983) Day-degree methods for pest management. Environ Entomol 12:613-619. doi:10.1093/ee/12.3.613

Qubbaj T, Reineke A, Zebitz CPW (2005) Molecular interactions between rosy apple aphids, Dysaphis plantaginea, and resistant and susceptible cultivars of its primary host Malus domestica. Entomol Exp Appl 115:145-152. doi:10.1111/j.1570-7458.2005.00255.x

Rahmati M, Davarynejad GH, Genard M, Bannayan M, Azizi M, Vercambre G (2015) Peach water relations, gas exchange, growth and shoot mortality under water deficit in semi-arid weather conditions. PLoS One 10:1-19. doi:10.1371/journal.pone.0120246

Rimbaud L, Dallot S, Gottwald T, Decroocq V, Jacquot E, Soubeyrand S, Thebaud G (2015) Sharka epidemiology and worldwide management strategies: learning lessons to optimize disease control in perennial plants. Annu Rev Phytopathol 53:357-378. doi:10.1146/ annurev-phyto-080614-120140

Rousselin A, Sauge MH, Jordan MO, Vercambre G, Lescourret F, Bevacqua D (2016) Nitrogen and water supplies affect peach treegreen peach aphid interactions: the key role played by vegetative growth. Agric For Entomol 18:367-375. doi:10.1111/afe.12168

Ryan GD, Sylvester EVA, Shelp BJ, Newman JA (2015) Towards an understanding of how phloem amino acid composition shapes elevated $\mathrm{CO}_{2}$-induced changes in aphid population dynamics. Ecol Entomol 40:247-257. doi:10.1111/een.12181

Ryan MG, Asao S (2014) Phloem transport in trees. Tree Physiol 34:1-4. doi:10.1093/treephys/tpt123

Saladini MA, Asteggiano L, Pansa MG, Giordani L, Serre L, Vittone G, Tavella L, Tedeschi R (2016) Glue barriers reduce earwig damage on apricots in north-western Italy. Int J Pest Manag 62:214-221. doi: 10.1080/09670874.2016.1178823

Satar S, Kersting U, Uygun N (2008) Effect of temperature on population parameters of Aphis gossypii Glover and Myzus persicae (Sulzer) (Homoptera: Aphididae) on pepper. J Plant Dis Prot 115:69-74

Sauge M-H, Grechi I, Poëssel J-L (2010) Nitrogen fertilization effects on Myzus persicae aphid dynamics on peach: vegetative growth allocation or chemical defence? Entomol Exp Appl 136:123-133. doi: 10.1111/j.1570-7458.2010.01008.x

Sauge M-H, Mus F, Lacroze J-P, Pascal T, Kervella J, Poëssel J-L (2006) Genotypic variation in induced resistance and induced suscepibility in the peach-Myzus persicae aphid system. Oikos 113:305-313. doi: 10.1111/j.2006.0030-1299.14250.x

Sauge MH, Kervella J, Pascal T (1998) Settling behaviour and reproductive potential of the green peach aphid Myzus persicae on peach varieties and a related wild Prunus. Entomol Exp Appl 89:233242. doi:10.1046/j.1570-7458.1998.00404.x

Sauge MH, Lacroze J-P, Poëssel J-L, Pascal T, Kervella J (2002) Induced resistance by Myzus persicae in the peach cultivar 'Rubira'. Entomol Exp Appl 102:29-37. doi:10.1046/j.1570-7458.2002.00922.x

Sauge MH, Lambert P, Pascal T (2011) Co-localisation of host plant resistance QTLs affecting the performance and feeding behaviour of the aphid Myzus persicae in the peach tree. Heredity 108:292301. doi:10.1038/hdy.2011.74 
Sevanto S (2014) Phloem transport and drought. J Exp Bot 65:17511759. doi:10.1093/jxb/ert467

Shan LT, Feng MG (2010) Evaluation of the biocontrol potential of various Metarhizium isolates against green peach aphid Myzus persicae (Homoptera: Aphididae). Pest Manag Sci 66:669-675. doi:10.1002/ ps. 1928

Silfver T, Sinkkonen A, Oksanen E, Rousi M (2014) Early shoot growth termination in Betula pendula is associated with the number of overwintering aphid eggs on boreal birches. Evol Ecol 29:157167. doi:10.1007/s10682-014-9741-8

Simon S, Bouvier J-C, Debras J-F, Sauphanor B (2010) Biodiversity and pest management in orchard systems. A review. Agron Sustain Dev 30:139-152. doi:10.1051/agro/2009013

Simon S, Brun L, Guinaudeau J, Sauphanor B (2011a) Pesticide use in current and innovative apple orchard systems. Agron Sustain Dev 31:541-555. doi:10.1007/s13593-011-0003-7

Simon S, Morel K, Durand E, Brevalle G, Girard T, Lauri P-É (2011b) Aphids at crossroads: when branch architecture alters aphid infestation patterns in the apple tree. Trees 26:273-282. doi:10.1007/ s00468-011-0629-8

Smith CM, Chuang WP (2014) Plant resistance to aphid feeding: behavioral, physiological, genetic and molecular cues regulate aphid host selection and feeding. Pest Manag Sci 70:528-540. doi:10.1002/ps. 3689

Spellman B, Brown MW, Mathews CR (2006) Effect of floral and extrafloral resources on predation of Aphis spiraecola by Harmonia axyridis on apple. BioControl 51:715-724. doi:10. 1007/s10526-005-5252-4

Stewart-Jones A, Pope TW, Fitzgerald JD, Poppy GM (2008) The effect of ant attendance on the success of rosy apple aphid populations, natural enemy abundance and apple damage in orchards. Agric For Entomol 10:37-43. doi:10.1111/j.1461-9563.2007.00353.x

Stoeckli S, Mody K, Dorn S (2008a) Aphis pomi (Hemiptera: Aphididae) population development, shoot characteristics, and antibiosis resistance in different apple genotypes. J Econ Entomol 101:1341-1348. doi:10.1603/0022-0493(2008)101[1341:APHAPD]2.0.CO;2

Stoeckli S, Mody K, Gessler C, Patocchi A, Jermini M, Dorn S (2008b) QTL analysis for aphid resistance and growth traits in apple. Tree Genet Genomes 4:833-847. doi:10.1007/s11295-008-0156-y

Symmes EJ, Dewhirst SY, Birkett MA, Campbell CA, Chamberlain K, Pickett JA, Zalom FG (2012) The sex pheromones of mealy plum
(Hyalopterus pruni) and leaf-curl plum (Brachycaudus helichrysi) aphids: identification and field trapping of male and gynoparous aphids in prune orchards. J Chem Ecol 38:576-583. doi:10.1007/ s10886-012-0121-y

Van Emden HF, Eastop VF, Hughes RD, Way MJ (1969) The ecology of Myzus persicae. Annu Rev Entomol 14:197-270. doi:10.1146/ annurev.en.14.010169.001213

VanWoerkom AH, Aćimović SG, Sundin GW, Cregg BM, Mota-Sanchez D, Vandervoort C, Wise JC (2014) Trunk injection: an alternative technique for pesticide delivery in apples. Crop Prot 65:173-185. doi:10.1016/j.cropro.2014.05.017

Verdugo JA, Francis F, Ramírez CC (2016) A review on the complexity of insect-plant interactions under varying levels of resources and host resistance: the case of Myzus persicae-Prunus persica. Biotechnol Agron Soc Environ 20:533-541

Wei JN, Bai BB, Yin TS, Wang Y, Zhao LH, Kuang RP, Xiang RJ (2005) Development and use of parasitoids (Hymenoptera: Aphidiidae \& Aphelinidae) for biological control of aphids in China. Biocontrol Sci Tech 15:533-551. doi:10.1080/09583150500086961

Wyss E (1995) The effects of weed strips on aphids and aphidophagous predators in an apple orchard. Entomol Exp Appl 75:43-49. doi:10. 1111/j.1570-7458.1995.tb01908.x

Wyss E, Niggli U, Nentwig W (1995) The impact of spiders on aphid populations in a strip-managed apple orchard. J Appl Entomol 119: 473-478. doi:10.1111/j.1439-0418.1995.tb01320.x

Wyss E, Villiger M, Hemptinne J-L, Müller-Schärer H (1999) Effects of augmentative releases of eggs and larvae of the ladybird beetle, Adalia bipunctata, on the abundance of the rosy apple aphid, Dysaphis plantaginea, in organic apple orchards. Entomol Exp Appl 90:167-173. doi:10.1046/j.1570-7458.1999.00435.x

Zhou H, Yu Y, Tan X, Chen A, Feng J (2014) Biological control of insect pests in apple orchards in China. Biol Control 68:47-56. doi:10. 1016/j.Biocontrol.2013.06.009

Zhou X, Feng M-G (2010) Improved sporulation of alginate pellets entrapping Pandora nouryi and millet powder and their potential to induce an aphid epizootic in field cages after release. Biol Control 54:153-158. doi:10.1016/j.biocontrol.2010.04.007

Zvereva EL, Lanta V, Kozlov MV (2010) Effects of sap-feeding insect herbivores on growth and reproduction of woody plants: a metaanalysis of experimental studies. Oecologia 163:949-960. doi:10. 1007/s00442-010-1633-1 